\title{
Beers AGS 2019 criteria in very old hospitalized patients
}

\author{
(D) Milton Luiz Gorzoni ${ }^{1}$ \\ (1D) Ronaldo Fernandes Rosa
}

1. Faculdade de Ciências Médicas da Santa Casa de São Paulo, São Paulo, SP, Brasil. 2. Irmandade da Santa Casa de Misericórdia de São Paulo, São Paulo, SP, Brasil.

http://dx.doi.org/10.1590/1806-9282.66.7.918

\section{SUMMARY}

OBJECTIVE: To define the rates and types of potentially inappropriate medications (PIMs) for older adults according to the Beers AGS 2019 criteria in oldest-old patients (aged $\geq 80$ years) hospitalized in an Internal Medicine ward.

METHODS: A retrospective analysis of prescriptions from medical records of oldest-old patients hospitalized in an Internal Medicine Teaching-Hospital ward using the Beers AGS 2019 criteria was performed. Data was also collected for gender, mean age, days of hospitalization, presence of feeding tube, delirium, and polypharmacy ( $\geq 5$ drugs/day). The drugs listed in Table 2 of the Beers criteria were considered PIMs.

RESULTS: The series comprised 39 very old patients (22 men, 17 women), with a mean age of $86.3 \pm 4.7$ years and hospitalization of $22.8 \pm 21.3$ days. All patients were admitted via the Emergency Room. Feeding tube placement and polypharmacy occurred in $84.6 \%$ of cases and delirium in 71.8\%. The prescription of a total of 16 drugs considered PIM was detected by the Beers AGS 2019 criteria (mean $1.8 \pm 1.0$ PIM per patient). Main prescribed PIMs were Metoclopramide "if necessary" [IN] (41.0\% of cases), Omeprazole (38.5\%), Regular Insulin [IN] (23.1\%), Haloperidol [IN] (18.0\%), Quetiapine and Amiodarone (10\% each).

CONCLUSION: In the present series of oldest-old hospitalized patients, significant rates of PIM were found, especially for drugs prescribed as "If Necessary", thereby increasing the risk of side-effects to that of the common polypharmacy in this age group.

KEYWORDS: Aged, 80 and over. Pharmaceutical preparations. Inpatients. Potentially inappropriate medication list.

\section{INTRODUCTION}

The natural process of aging - accompanied or not by the changes resulting from diseases of higher prevalence among the elderly - represents a potential for interference on the pharmacokinetics and pharmacodynamics of the human body with a significant number of medications. This relationship is often observed in clinical practice, given the high percentage of patients in this age group who simultaneously and chronically take several medications ${ }^{1.2}$.
Thus, it is easy to observe the medications that have a greater potential to harm than to benefit elderly patients. Defined as potentially inappropriate medications (PIM), these drugs resulted in the development of multiple lists and criteria with the purpose of guiding their use by patients of more advanced ages ${ }^{3.4}$. The Beers criteria - now in its sixth edition - are the most commonly used and worldwide renowned list of $\mathrm{PIM}^{5}$. Its previous editions served as a reference to a

DATE OF SUBMISSION: 14-Jan-2020

DATE OF ACCEPTANCE: 19-Jan-2020

CORRESPONDING AUTHOR: Milton Luiz Gorzoni

Rua Doutor Cesário Motta Júnior, 112 - São Paulo, SP, Brasil - 01221-020

Tel:+55 112176-7300 / Fax: +55 115589-9408

E-mail: gorzoni@uol.com.br 
significant number of national studies, particularly for the Brazilian Consensus on Potentially Inappropriate Medications for the Elderly (2016) ${ }^{6}$.

It is estimated that hospitalized elderly individuals take five or more medications simultaneously - defined as polypharmacy -, and one or more PIM may be present in percentages that deserve the attention of healthcare professionals ${ }^{7.8}$. It is estimated that the so-called "iatrogenic triad" - polypharmacy, drug interactions, and PIM - occurs in approximately one-third of elderly individuals who take medications ${ }^{9}$.

Considering the fact that very old individuals - age greater than or equal to 80 years - are exposed to situations of fragility and reduction of functional capacity, the analysis of PIM during hospitalizations is worthy of attention and the motivation for the present study ${ }^{10.11}$.

The goal of this study is to define the percentages and types of potentially inappropriate medications (PIM) for the elderly based on the Beers criteria AGS $2019^{5}$ in the patients of very old age ( $\geq 80$ years) hospitalized in the internal medicine ward of a tertiary hospital.

\section{METHODS}

A retrospective analysis of prescriptions from the medical records of very old patients hospitalized in the internal medicine ward of a tertiary hospital from 01/01/2018 to 27/10/2018, based on the Beers criteria AGS 2019. We considered as PIM the medications listed in Table 2 of these criteria 5 . We adapted that table for the medications approved for use in Brasil by the Brazilian Health Regulatory Agency (Anvisa), according to data on their website on 23 July $2019^{12}$ (Table 1 of this study).

Other data collected: (1) gender, (2) mean age and standard deviation (3) days of hospitalization (mean and standard deviation), (4) presence of feeding tube (nasoenteral, nasogastric, or gastrostomy) based on the presence of medications with a contraindication for this route ${ }^{13}$, (5) delirium (based on the Portuguese version of the Confusion Assessment Method ${ }^{14}$ ) justified due to the usual prescription of psychotropic drugs ${ }^{15}$, (6) polypharmacy (use of five or more medications/ day $^{7}$ ).

Statistical analysis of the data was based on the presence or absence of a certain PIM regarding gender and age groups ( 80 to 89 years and equal to or greater than 90 years). We used Fisher's exact test with an alpha value of 0.05 .
After being submitting the study to the Human Research Ethics Committee (CEP) of the institution to which the authors are part of and considering that the present study does not involve humans, the Committee considered there was no need to issue an opinion for it.

\section{RESULTS}

During the period of this study (300 days), 39 very old patients (22 men and 17 women) with a mean age of $86.3 \pm 4.7$ years ( 80 to 98 years) were hospitalized in the internal medicine ward (approximate one hospitalization per week). The present sample was composed entirely of admissions from the emergency room, with an average of $22.8 \pm 21.3$ days ( 3 to 129 days) of hospitalization. There as a need for oxygen supply and/ or polypharmacy in $84.6 \%$ of cases and a diagnosis of delirium in $71.8 \%$.

We detected the prescription of 16 drugs considered PIM based on the Beers criteria AGS $2019^{5}$ (Table 2 of this study) - an average of $1.8 \pm 1$.0 PIM per patient - (70 PIM/39 patients with extremes of 0 and 4 PIM). Main prescribed PIM (Figure 1): (1) metoclopramide, if necessary [IN] (41.0\% of cases), (2) omeprazole (38.5\%), (3) regular insulin [IN] (23.1\%), (4) haloperidol [IN] (18.0\%), (5 and 6) quetiapine and amiodarone (10\% each). The final sum resulted in $70 \mathrm{PIM} / 39$ patients.

We found statistically significant relationships between the absence or non-use of haloperidol, metoclopramide, and omeprazole in very old men grouped by age ( 80 to 89 years, 90 years or more). The statistical significance of haloperidol was based on the absence of use, and that of metoclopramide and omeprazole on their higher use by nonagenarians. Omeprazole was also statistically significant among elderly women, with a tendency to non-prescription for octogenarians.

\section{DISCUSSION}

The rapid process of population aging in Brasil and, consequently, the increase in hospitalizations in this age group deserves special attention from healthcare professionals ${ }^{16}$.

Very old patients are noteworthy for the occurrence of three or more conditions - chronic-degenerative and concomitant $-66.0 \%$ more frequently than among quinquagenarians ${ }^{17}$. When there is an acute event and/or the decompensation of previous 
TABLE 1. BEERS CRITERIA 2019 AGS $^{\circledR}$ FOR POTENTIALLY INAPPROPRIATE MEDICATIONS FOR THE ELDERLY5. MEDICATIONS LICENSED FOR USE IN BRASIL ${ }^{\mathbf{2}}$.

\begin{tabular}{|c|c|c|c|c|c|c|c|}
\hline \multicolumn{8}{|c|}{ Therapeutic Class } \\
\hline $\begin{array}{l}\text { Central al- } \\
\text { pha-agonists } \\
\text { Clonidine } \\
\text { (for first-line } \\
\text { treatment of } \\
\text { hypertension) } \\
\text { Guanabenz } \\
\text { Guanfacine } \\
\text { Methyldopa } \\
\text { Reserpine } \\
\text { (>0.1 mg/day) }\end{array}$ & $\begin{array}{l}\text { Antidepressants } \\
\text { Amitriptyline } \\
\text { Amoxapine } \\
\text { Clomipramine } \\
\text { Desipramine } \\
\text { Doxepin (>6 mg/ } \\
\text { day) } \\
\text { Imipramine } \\
\text { Nortriptyline } \\
\text { Paroxetine } \\
\text { Protriptyline } \\
\text { Trimipramine }\end{array}$ & \multirow{2}{*}{$\begin{array}{l}\text { First-Generation } \\
\text { Antihistamines } \\
\text { Brompheniramine } \\
\text { Carbinoxamine } \\
\text { Chlorpheniramine } \\
\text { Clemastine } \\
\text { Cyproheptadine } \\
\text { Dexbrompheni- } \\
\text { ramine } \\
\text { Dexchlorpheni- } \\
\text { ramine } \\
\text { Dimenhydrinate } \\
\text { Diphenhydramine } \\
\text { (oral) } \\
\text { Doxylamine } \\
\text { Hydroxyzine } \\
\text { Meclizine } \\
\text { Pyrilamine or } \\
\text { Mepyramine } \\
\text { Promethazine } \\
\text { Triprolidine }\end{array}$} & $\begin{array}{l}\text { Antiparkinso- } \\
\text { nian Drugs } \\
\text { Benzatropine } \\
\text { (oral) } \\
\text { Trihexyphenidyl }\end{array}$ & $\begin{array}{l}\text { Barbiturates } \\
\text { Amobarbital } \\
\text { Butabarbital } \\
\text { Butalbital } \\
\text { Mephobarbital } \\
\text { Pentobarbital } \\
\text { Phenobarbital } \\
\text { Secobarbital }\end{array}$ & $\begin{array}{l}\text { Genitourinary } \\
\text { drugs } \\
\text { Desmopressin }\end{array}$ & $\begin{array}{l}\text { Hormones } \\
\text { Androgens } \\
\text { Methyltestos- } \\
\text { terone } \\
\text { Testosterone } \\
\text { Other hor- } \\
\text { mones } \\
\text { Thyroid extract } \\
\text { Estrogen with } \\
\text { or without } \\
\text { progesterone } \\
\text { Growth hor- } \\
\text { mone } \\
\text { Megestrol }\end{array}$ & $\begin{array}{l}\text { Other } \\
\text { Anxiolytics } \\
\text { Meprobamate }\end{array}$ \\
\hline \multirow[t]{2}{*}{$\begin{array}{l}\text { Peripheral } \\
\text { Alpha-1 } \\
\text { blockers for } \\
\text { hypertension } \\
\text { treatment } \\
\text { Doxazosin } \\
\text { Prazosin } \\
\text { Terazosin }\end{array}$} & \multirow{3}{*}{$\begin{array}{l}\text { Antispasmodics } \\
\text { Atropine } \\
\text { (excludes oph- } \\
\text { thalmic use) } \\
\text { Belladonna } \\
\text { alkaloids } \\
\text { Chlordiazepox- } \\
\text { ide-clidinium } \\
\text { Dicyclomine } \\
\text { Homatropine } \\
\text { (excludes oph- } \\
\text { thalmic use) } \\
\text { Hyoscyamine } \\
\text { Methscopol- } \\
\text { amine } \\
\text { Propantheline } \\
\text { Scopolamine }\end{array}$} & & \multirow[t]{2}{*}{$\begin{array}{l}\text { Antipsychotics } \\
\text { First generation } \\
\text { (conventional) } \\
\text { and } \\
\text { Second gener- } \\
\text { ation } \\
\text { (atypical) }\end{array}$} & \multirow{2}{*}{$\begin{array}{l}\text { Benzodiazepines } \\
\text { Short or intermedi- } \\
\text { ate action } \\
\text { Alprazolam } \\
\text { Estazolam } \\
\text { Lorazepam } \\
\text { Oxazepam } \\
\text { Temazepam } \\
\text { Triazolam } \\
\text { Prolonged Action } \\
\text { Chlordiazepoxide } \\
\text { (alone or associat- } \\
\text { ed to amitriptyline } \\
\text { or clidinium) } \\
\text { Clonazepam } \\
\text { Clorazepate } \\
\text { Diazepam } \\
\text { Flurazepam } \\
\text { Quazepam }\end{array}$} & $\begin{array}{l}\text { Nonbenzodiaz- } \\
\text { epine hypnotics } \\
\quad \text { (Z-drugs) } \\
\text { Eszopiclone } \\
\text { Zaleplon } \\
\text { Zolpidem }\end{array}$ & \multirow[t]{2}{*}{$\begin{array}{l}\text { Muscle } \\
\text { Relaxants } \\
\text { Carisoprodol } \\
\text { Chlorzoxazone } \\
\text { Cyclobenzap- } \\
\text { rine } \\
\text { Methocarbamol } \\
\text { Orphenadrine }\end{array}$} & \multirow{2}{*}{$\begin{array}{l}\text { Other car- } \\
\text { diovascular } \\
\text { action drugs } \\
\text { Amiodarone } \\
\text { Disopyramide } \\
\text { Dronedarone } \\
\text { Digoxin } \\
\text { (as first-line } \\
\text { treatment for } \\
\text { atrial fibrilla- } \\
\text { tion or heart } \\
\text { failure) } \\
\text { Nifedipine }\end{array}$} \\
\hline & & $\begin{array}{l}\text { Non-steroidal } \\
\text { anti-inflammatory } \\
\text { drugs } \\
\text { Acetylsalicylic acid } \\
\text { (>325 mg/day) } \\
\text { Mefenamic acid } \\
\text { Ketoprofen } \\
\text { Ketorolac } \\
\text { (including paren- } \\
\text { teral) } \\
\text { Diclofenac } \\
\text { Diflunisal }\end{array}$ & & & \multirow[t]{2}{*}{$\begin{array}{l}\text { Hypoglycemic } \\
\text { Drugs } \\
\text { Sulfonylureas of } \\
\text { prolonged action } \\
\text { Chlorpropamide } \\
\text { Glimepiride } \\
\text { Glyburide or } \\
\text { Glibenclamide } \\
\text { Short or } \\
\text { fast-acting } \\
\text { insulins } \\
\text { (in a scheme } \\
\text { according to } \\
\text { capillary glyce- } \\
\text { mia) }\end{array}$} & & \\
\hline $\begin{array}{l}\text { Antibiotics } \\
\text { Nitrofurantoin }\end{array}$ & & $\begin{array}{l}\text { Etodolac } \\
\text { Fenoprofen } \\
\text { Ibuprofen } \\
\text { Indomethacin } \\
\text { Meclofenamate } \\
\text { Meloxicam } \\
\text { Nabumetone } \\
\text { Naproxen } \\
\text { Piroxicam } \\
\text { Sulindac } \\
\text { Tolmetin }\end{array}$ & $\begin{array}{l}\text { Antithrombotic } \\
\text { drugs } \\
\text { Dipyridamole } \\
\text { (oral, short- } \\
\text { term) }\end{array}$ & $\begin{array}{l}\text { Gastrointestinal } \\
\text { tract } \\
\text { Metoclopramide } \\
\text { Mineral oil (oral) } \\
\text { Proton-pump } \\
\text { inhibitor }\end{array}$ & & $\begin{array}{l}\text { Opioids } \\
\text { Meperidine }\end{array}$ & $\begin{array}{l}\text { Vasodilators } \\
\text { of dubious } \\
\text { efficacy } \\
\text { Ergoloid } \\
\text { mesylates } \\
\text { Isoxsuprine }\end{array}$ \\
\hline
\end{tabular}

diseases, the risk of hospitalization in very old patients reaches $13.6 \%$ in 12 months, in contrast to $8.9 \%$ for those aged between 50 and 59 years ${ }^{18}$. Both situations - multimorbidities and hospitalizations lead to the simultaneous and progressive use of five or more medications daily in approximately $20.0 \%$ of elderly patients ${ }^{19}$. This therapeutic process presents a risk for adverse reactions to medications in percentages above $60.0 \%$ of hospitalized patients and to the use of PIMs ${ }^{3.20}$.

Considering the above, it is recommended that the concept of PIM - which present a higher chance of adverse events than benefits - become part of clinical practice in the care for patients of this age group. The prescription of medications must be considered a potentially iatrogenic and lethal act, especially when there is evidence and/or alternatives of other medicines with equal or better effectiveness and that are safer for the pharmacological treatment of the patient under evaluation ${ }^{3.6}$.

Very old patients often become prone to the so-called "iatrogenic triad" - polypharmacy, PIM, and drug interactions - a situation that can be prevented and in which criteria such as the Beers allow health professionals to take appropriate therapeutic decisions $^{3-5,9}$.

The fact that PIMs (haloperidol, insulin, and metoclopramide) are listed as "prescribed if necessary" does not minimize their potentially inappropriate indication to very old patients. It is inferred that the application of insulin with capillary blood glucose monitoring and the indication for metoclopramide for occasional vomiting incurs the false impression that episodic use does not lead to side effects and/or drug interactions. When talking about PIM, the frequency with which "if necessary" medications are used to 
TABLE 2. MEDICATIONS CONSIDERED POTENTIALLY INAPPROPRIATE FOR THE ELDERLY BASED ON THE BEERS CRITERIA AGS 20195 AND OBSERVED IN PRESCRIPTIONS OF VERY OLD PATIENTS HOSPITALIZED IN THE INTERNAL MEDICINE WARD OF A TERTIARY HOSPITAL (7O MEDICATIONS/39 USERS).

\begin{tabular}{|c|c|c|c|c|c|c|}
\hline \multirow{3}{*}{$\begin{array}{l}\text { Potentially inappropriate } \\
\text { medications for the elderly }\end{array}$} & \multirow{2}{*}{\multicolumn{2}{|c|}{$\begin{array}{l}\text { Women } \\
\text { Age (years) }\end{array}$}} & \multirow{2}{*}{\multicolumn{2}{|c|}{$\begin{array}{c}\text { Men } \\
\text { Age (years) }\end{array}$}} & \multirow{3}{*}{$\begin{array}{l}\text { Total number } \\
\text { of users }\end{array}$} & \multirow{3}{*}{$\begin{array}{l}\text { Percentage of } \\
\text { users }\end{array}$} \\
\hline & & & & & & \\
\hline & 80 to 89 & 90 or + & 80 to 89 & 90 or + & & \\
\hline Amiodarone & - & - & 4 & - & 4 & 10.0 \\
\hline Atropine & - & - & 1 & 1 & 2 & 5.0 \\
\hline Clonazepam & 1 & - & - & - & 1 & 2.6 \\
\hline Diazepam & - & - & 1 & - & 1 & 2.6 \\
\hline Digoxin & - & - & 1 & - & 1 & 2.6 \\
\hline Doxazosin & - & - & 2 & - & 2 & 5.0 \\
\hline HaloperidolIN $^{\mid N}$ & - & 2 & $3^{\#}$ & $2^{\#}$ & 7 & 18.0 \\
\hline Insulin ${ }^{\mid N}$ & 4 & - & 4 & 1 & 9 & 23.1 \\
\hline Methyldopa & 1 & - & - & - & 1 & 2.6 \\
\hline Metoclopramide ${ }^{\mathrm{IN}}$ & 5 & 1 & $7^{+}$ & $3^{+}$ & 16 & 41.0 \\
\hline Mineral oil & - & - & 3 & - & 3 & 7.7 \\
\hline Omeprazole & $4^{\prime}$ & $2^{\prime}$ & $6^{\prime \prime}$ & 3" & 15 & 38.5 \\
\hline Quetiapine & 1 & - & 1 & 2 & 4 & 10.0 \\
\hline Risperidone & - & - & 2 & - & 2 & 5.0 \\
\hline Tramadol & 1 & - & - & - & 1 & 2.6 \\
\hline Zolpidem & - & - & 1 & - & 1 & 2.6 \\
\hline
\end{tabular}

${ }^{*}=$ Eye drops, ${ }^{S_{n}}=$ If necessary, ${ }^{*} p=0.0240, p=0.0322, p=0.0251, p=0.0249$

The sum of the percentages is greater than $100.0 \%$ since in this sample there are very old individuals who took more than one potentially inappropriate medication.

FIGURE 1. MAIN MEDICATIONS CONSIDERED POTENTIALLY INAPPROPRIATE FOR THE ELDERLY BASED ON THE BEERS CRITERIA AGS 20195 AND OBSERVED IN PRESCRIPTIONS OF VERY OLD PATIENTS HOSPITALIZED IN THE INTERNAL MEDICINE WARD OF A TERTIARY HOSPITAL (7O MEDICATIONS/39 USERS).

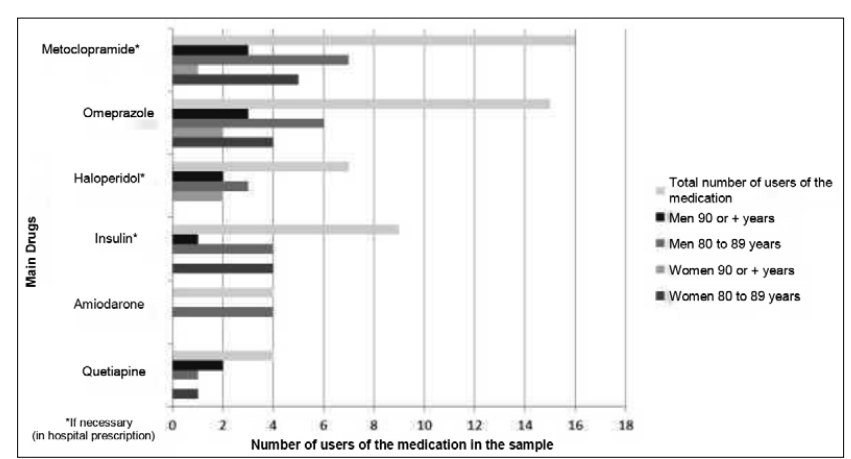

be noted, since - depending on the clinical condition - their use can become daily and not episodic ${ }^{5}$. The same circumstance was observed in the indication of haloperidol for very old patients with conditions of delirium and/or severe cognitive dysfunction since there is a risk that doses administered without a criterion of maximum value might exceed the dose of 5 $\mathrm{mg} / 24$ hours $^{15}$. Thus, the standard from the place of origin of the present sample, which adds up the total doses and their milligrams, is justified to reduce the risk of adverse reactions to these medications.
Another routine in the infirmary dynamics, on which this study is based, refers to medications and feeding tubes. The indication for nutrition via alternative routes is common among the elderly - notably among very old ones - who are hospitalized. However, not all medications are able to fully accomplish their function via these routes. The Beers criteria do not comment on this aspect of the medicines analyzed in this series - digoxin, haloperidol, omeprazole, and tramadol -, which have non-crushable presentations or that precipitate with an enteral diet ${ }^{5.13}$. This constitutes, thus, a curious situation, in which the PIM not only is contraindicated due to a greater probability of adverse events but also for the possibility of not being absorbed in this route of administration. The association of such details is worthy of mention due to the false sense of correct prescription to very old patients with overlapping iatrogenesis, i.e., from the medication (PIM) and the procedure (feeding tubes) ${ }^{21}$.

The prescription of omeprazole in over one-third of very old patients justifies two comments. The medication was long considered a low hazard for the elderly, and the Beers criteria included it as a PIM just in its

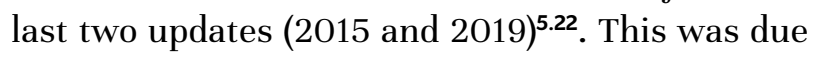
to reports on adverse events during its chronic use (for more than eight weeks daily), especially among patients in this age group ${ }^{23}$. Omeprazole is currently 
related to falls and fractures, Clostidium difficile infections, community-acquired pneumonia, vitamin B12 deficiency, dementia, injury, and kidney disease ${ }^{23}$. The second comment, which is also a relevant factor, relates to reports that approximately $63.0 \%$ of users of this proton-pump inhibitor do not exhibit gastrointestinal symptoms, diagnosis of diseases of the digestive system, and/or the simultaneous use of other medications with the potential for gastrointestinal lesions ${ }^{23}$. It is recommended that, prior to the prescription of a proton-pump inhibitor, a careful evaluation of medications in use be conducted to define the therapeutic purpose of each of them. By doing this, it is possible to have a simple and low-cost mechanism that can reduce the indices of polypharmacy among the elderly - notably very old ones -, creating a culture of de-prescription, something that is being developed at the hospital of origin of the present sample ${ }^{24}$.

It is inferred that the presence of psychotropic drugs - clonazepam, diazepam, haloperidol, risperidone, quetiapine, and zolpidem - is this sample is due to the high percentage of cases of acute mental confusion, (delirium). It is important to note that the number of users of this pharmacological group is smaller than the percentage of patients with delirium in this study. This discrepancy is justified by the hospital protocol for early detection of acute confusional states on the site that originated sample, which enables the use of non-pharmacological measures and a reduction in prescriptions of psychotropic drugs ${ }^{15}$.

The present sample - of convenience - does not allow the full generalization of the results but exposes a concrete need for the rational systematization of prescriptions for elderly patients, especially very old ones. There are tools available for that, with emphasis on PIM lists, particularly the Beers criteria ${ }^{5.22}$.

\section{CONCLUSION}

Very old patients hospitalized and evaluated in this study based on the Beers criteria AGS 2019 showed a significant percentage of PIM, in particular, those indicated as "if necessary". This increases the risk of side effects due to the high frequency of polypharmacy in this age group and indicates the need for the systematization of therapeutic care in very old patients.

\section{Author's Contribution}

Milton Luiz Gorzoni - Data collection and analysis. Initial draft of the manuscript; Ronaldo Fernandes Rosa - Original concept, adaptation of the Beers AGS 2019 criteria to this study and revision of the manuscript.

\section{RESUMO}

OBJETIVO: Definir percentual e tipos de medicamentos potencialmente inapropriados para idosos (MPII) pelos critérios de Beers AGS 2019 em longevos (idade $\geq 80$ anos) hospitalizados em enfermaria de clínica médica.

MÉTODO: Análise retrospectiva das prescrições de prontuários de longevos internados em enfermaria de clínica médica de hospital terciário pelos critérios de Beers AGS 2019. Outros dados coletados: gênero, idade média, dias de hospitalização, presença de sonda de alimentação, delirium, polifarmácia ( $\geq 5$ fármacos/dia). Consideraram-se como MPll os fármacos listados na Tabela 2 do referido critério.

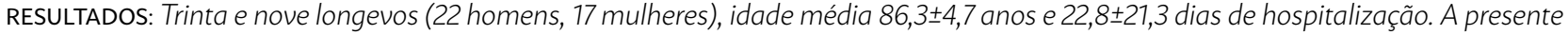
casuística foi integralmente admitida pelo pronto-socorro, ocorrendo sonda de alimentação e polifarmácia em 84,6\% dos casos e delirium

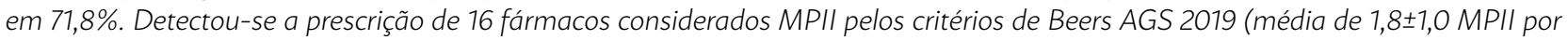
paciente). Principais MPII prescritos: metoclopramida, se necessário [SN] (41,0\% dos casos), omeprazol (38,5\%), insulina regular [SN] (23,1\%), haloperidol [SN] (18,0\%), quetiapina e amiodarona (10\% cada).

CONCLUSÃO: Na presente casuística, longevos hospitalizados apresentaram percentuais significativos de MPII, notadamente em fármacos indicados como "se necessário", o que aumenta o risco de efeitos colaterais ao fato comum de polifarmácia nessa faixa etária.

PALAVRAS-CHAVE: Idoso de 80 anos ou mais. Preparações farmacêuticas. Pacientes internados. Lista de medicamentos potencialmente inapropriados. 


\section{REFERENCES}

1. McLean AJ, Le Couteur DG. Aging biology and geriatric clinical pharmacology. Pharmacol Rev. 2004;56(2):163-84.

2. Koren G, Nordon G, Radinsky K, Shalev V. Clinical pharmacology of old age. Expert Rev Clin Pharmacol. 2019;12(8):749-55.

3. Gorzoni ML, Fabbri RM, Pires SL. Potentially inappropriate medications in elderly. Rev Assoc Med Bras. 2012;58(4):442-6.

4. Lucchetti G, Lucchetti AL. Inappropriate prescribing in older persons: systematic review of medications available in different criteria. Arch Geronto Geriatr. 2017;68:55-61.

5. American Geriatrics Society Beers Criteria ${ }^{\oplus}$ Update Expert Panel. American Geriatrics Society 2019 Updated AGS Beers criteria ${ }^{\circledR}$ for potentially inappropriate medication use in older adults. J Am Geriatr Soc. 2019;67(4):674-94.

6. Oliveira MG, Amorim WW, Borja-Oliveira CR, Coqueiro HL, Gusmão LC, Passos LC. Consenso brasileiro de medicamentos potencialmente inapropriados para idosos. Geriatr Gerontol Aging. 2016;10(4):168-81.

7. Assis DL, Chagas VO, Valente M, Gorzoni ML. Polifarmácia e uso de medicamentos inapropriados em idosos institucionalizados: lições ainda não aprendidas. Geriatr Gerontol Aging. 2016;10:126-31.

8. Juliano ACDSRS, Lucchetti ALG, Silva ITSD, Santos LG, Nunes IBT, Fernandes GC, et al. Inappropriate prescribing in older hospitalized adults: a comparison of medical specialties. J Am Geriatr Soc. 2018;66(2):383-8.

9. Novaes PH, Cruz DT, Lucchetti ALG, Leite ICG, Lucchetti G. The "iatrogenic triad": polypharmacy, drug-drug interactions, and potentially inappropriate medications in older adults. Int J Clin Pharm. 2017;39(4):818-25.

10. Nogueira SL, Ribeiro RCL, Rosado LEFPL, Franceschini SCC, Ribeiro AQ Pereira ET. Fatores determinantes da capacidade funcional em idosos longevos. Rev Bras Fisioter. 2010;14(4):322-9.

11. Liberalesso TEM, Dallazen F, Bandeira VAC, Berlezi EM. Prevalência de fragilidade em uma população de longevos na região sul do Brasil. Saúde Debate. 2017;41(113):553-62.

12. Brasil. Agência Nacional de Vigilância Sanitária (ANVISA). Consulta a produtos regularizados. [cited 2019 Jul 23]. Available from: https://consultas. anvisa.gov.br/\#/medicamentos/
13. Gorzoni ML, Della Torre A, Pires SL. Medicamentos e sondas de nutrição. Rev Assoc Med Bras. 2010;56(1):17-21.

14. Fabbri RM, Moreira MA, Garrido R, Almeida OP. Validity and reliability of the Portuguese version of the Confusion Assessment Method (CAM) for the detection of delirium in the elderly. Arq Neuropsiquiatr. 2001;59(2-A):175-9.

15. Potter J, George J; Guideline Development Group. The prevention, diagnosis and management of delirium in older people: concise guidelines. Clin Med (Lond). 2006;6(3):303-8.

16. Gorzoni ML, Lima CAC. Análise dos parâmetros clínicos de idosos internados em enfermaria de Clínica Médica. Rev Assoc Med Bras. 1995;41(3):227-32.

17. Nunes BP, Batista SRR, Andrade FB, Souza-Júnior PRB, Lima-Costa MF, Facchini LA. Multimorbidade em indivíduos com 50 anos ou mais de idade: ELSI-Brasil. Rev Saude Publica. 2018;52(Supl 2):10s.

18. Melo-Silva AM, Mambrini JVM, Souza-/únior PRB, Andrade FB, Lima-Costa MF. Hospitalizações entre adultos mais velhos: resultados do ELSI-Brasil. Rev Saude Publica. 2018;52(Supl 2):3s.

19. Loyola-Filho Al, Firmo JOA, Mambrini JVM, Peixoto SV, Souza-Júnior PRB Andrade FB, et al. Subutilização de medicamentos por motivos financeiros em adultos mais velhos: ELSI-Brasil. Rev Saude Publica. 2018;52(Supl 2):8s.

20. Passarelli MCG, Jacob-Filho W. Reações adversas a medicamentos em idosos: como prevê-las? Einstein. 2007;5(3):246-51.

21. Pereira AC, Franken RA, Sprovieri SRS, Golin V. latrogenia e cardiologia. Arg Bras Cardiol. 2000;75(1):75-8.

22. American Geriatrics Society 2015 Beers criteria update expert panel. American Geriatrics Society 2015 updated Beers criteria for potentially inappropriate medication use in older adults. J Am Geriatr Soc. 2015;63(11):2227-46.

23. Maes ML, Fixen DR, Linnebur SA. Adverse effects of proton-pump inhibitor use in older adults: a review of the evidence. Ther Adv Drug Saf. 2017;8(9):273-97.

24. Farrell B, Tsang C, Raman-Wilms L, Irving H, Conklin I, Pottie K. What are priorities for deprescribing for elderly patients? Capturing the voice of practitioners: a modified Delphi process. PLoS One. 2015;10(4):e0122246. 